\title{
All Hands on Deck: Local Ecological Knowledge and Expert Volunteers Contribute to the First Delisting of a Marine Fish Species Under the Endangered Species Act
}

\author{
Kelly Andrews*, Krista Nichols*, Chris Harvey*, Nick Tolimieri*, Adam Obaza ${ }^{\dagger}$, Ron Garner \\ and Daniel Tonnes ${ }^{\S}$
}

The listing of three species of rockfish (Sebastes spp.) under the Endangered Species Act (ESA) in 2010 motivated the development of a cooperative research program between government agencies and the local recreational fishing and SCUBA diving communities of Puget Sound (PS), WA, USA. This program has examined rockfish life history characteristics, movement behavior, young-of-year recruitment and the population responses to fishing in PS. Of most significance has been the involvement of the recreational fishing community in testing whether the three ESA-listed rockfish populations in PS were genetically discrete from populations outside of PS. There was considerable uncertainty in the answer to this question during the original ESA listing process due to limited data on these three species in PS. We used the knowledge and expert angling skills of the fishing community to locate these rare species and non-lethally collect tissue samples for genetic analyses. Results showed that yelloweye rockfish (S. ruberrimus) was genetically differentiated between PS and the outer coast, but the boundaries of the population were different than previously assumed. In contrast, canary rockfish (S. pinniger) was genetically similar across PS and the outer coast. Federal managers used these results to expand the ESA-listed boundaries of yelloweye rockfish and to delist canary rockfish - the first delisting of a marine fish species from the ESA. The knowledge and angling expertise of the Puget Sound recreational fishing community were directly responsible for the successful collection of data to test hypotheses that resulted in very specific management decisions.

Keywords: rockfish; adaptive management; recreational fishing; population structure; Puget Sound; citizen science

\begin{abstract}
Introduction
The management of natural resources is often disrupted because of considerable uncertainty in the decision-making process. Adaptive management serves as a framework to progressively reduce uncertainty through a series of structured steps (Holling 1978; Walters 1986; Lee 1993). Greatly simplified (see detailed review in Murphy and Weiland 2014), adaptive management begins with a formal evaluation of the question at hand and the outcomes of alternative management actions using the best available science. An initial decision is made after analyzing and integrating the tradeoffs among conservation and stakeholder objectives. The process continues by imple-
\end{abstract}

\footnotetext{
* Northwest Fisheries Science Center, National Marine Fisheries Service, National Oceanic and Atmospheric Administration, US + Paua Marine Research Group, US

₹ Puget Sound Anglers, US

$\S$ West Coast Regional Office, National Marine Fisheries Service, National Oceanic and Atmospheric Administration, US

Corresponding author: Kelly Andrews (kelly.andrews@noaa.gov)
}

menting a monitoring plan capable of collecting new data to address uncertainties in the decision and to test a set of prioritized hypotheses to fill relevant knowledge gaps. The cycle ends with management responding to these new sets of data with affirmation or changes to public policy.

This process, however, is often derailed at the very beginning owing to the lack of data to make a formal evaluation of the problem and to make definitive management decisions, particularly when dealing with rare, threatened, or endangered species (Sutherland et al. 2004; Bland and Collen 2016). In many instances, scientific evaluations of the status of a species with limited data conclude with a species simply being categorized as "data-deficient" (IUCN 2018) or a government agency dismissing a petition due to insufficient information to move forward (NMFS 2007a; Kelly et al. 2017). Data deficiencies and information gaps for species-of-concern generally persist through most stages of the management process, beginning with the initial task of determining whether a species or population is at risk and meets the criteria to be listed and/or protected, through efforts to monitor population abundance and determine causes of risk, to final conclusions about recovery of a 
species (Doremus 2008; Harris et al. 2012; Bland et al. 2017). In these situations, it is imperative to take advantage of any and all sources of knowledge and expertise.

Citizen science can be an invaluable tool in obtaining relevant and necessary data in data-poor and limited-funding situations. Local user groups and stakeholders gain knowledge from their daily observations of a species or particular areas, and many become experts in the spatial and temporal distribution of their target species or habitat. Including expertise from non-scientists, often called local or traditional ecological knowledge (Huntington 2000), in the formal scientific process has received much attention over the last decade (Anadón et al. 2009; Azzurro et al. 2011; Beaudreau and Levin 2014; Bastari et al. 2017) and has been recognized as an important step in our ability to make the best management and public policy decisions, particularly in data-poor situations (Bonney et al. 2009; Tulloch et al. 2013).

In this paper, we present an example of collaboration and engagement between the management, scientific, and stakeholder communities that integrated expertise across the communities which resulted in changes to previous public policy decisions and provided a framework for future scientific and management endeavors. Our goal is to show how citizen science input and research support was absolutely essential to achieving a positive policy outcome: The delisting of a species from protection under the US Endangered Species Act (ESA) based on sound science. Specifically, three species of rockfish (Sebastes spp.) were listed under the ESA in Puget Sound, WA, USA, although that decision was made in an extremely data-poor scientific environment (Drake et al. 2010). Subsequent research to fill crucial data gaps relied heavily on 1) the local ecological knowledge of the recreational fishing community for locating these rare rockfish species and 2) their bottom fishing expertise for collecting enough genetic samples of these rockfishes (Andrews et al. 2018). The samples collected owing to their knowledge and skill provided new information on rockfish population structure (Andrews et al. 2018) and led to the delisting of one threatened rockfish species and the broadening of population boundaries for a second threatened species (NMFS 2017a). Here, we describe the public policy issue and efforts to engage stakeholder communities in the Puget Sound region, provide summaries of stakeholder contributions to scientific results and management decisions, and conclude with descriptions of secondary benefits of the collaboration among the three communities.

\section{The public policy issue on the table}

In 2010, the U.S. National Marine Fisheries Service (NMFS) listed three species of rockfish in the Puget Sound/Georgia Basin (PSGB) region of Washington State (PSGB; Figure 1) either as "threatened" (yelloweye rockfish Sebastes ruberrimus and canary rockfish $S$. pinniger) or "endangered" (bocaccio S. paucispinis) in accordance with the ESA (NMFS 2010). These listings were designated based on research and analyses conducted by NMFS's Bio-

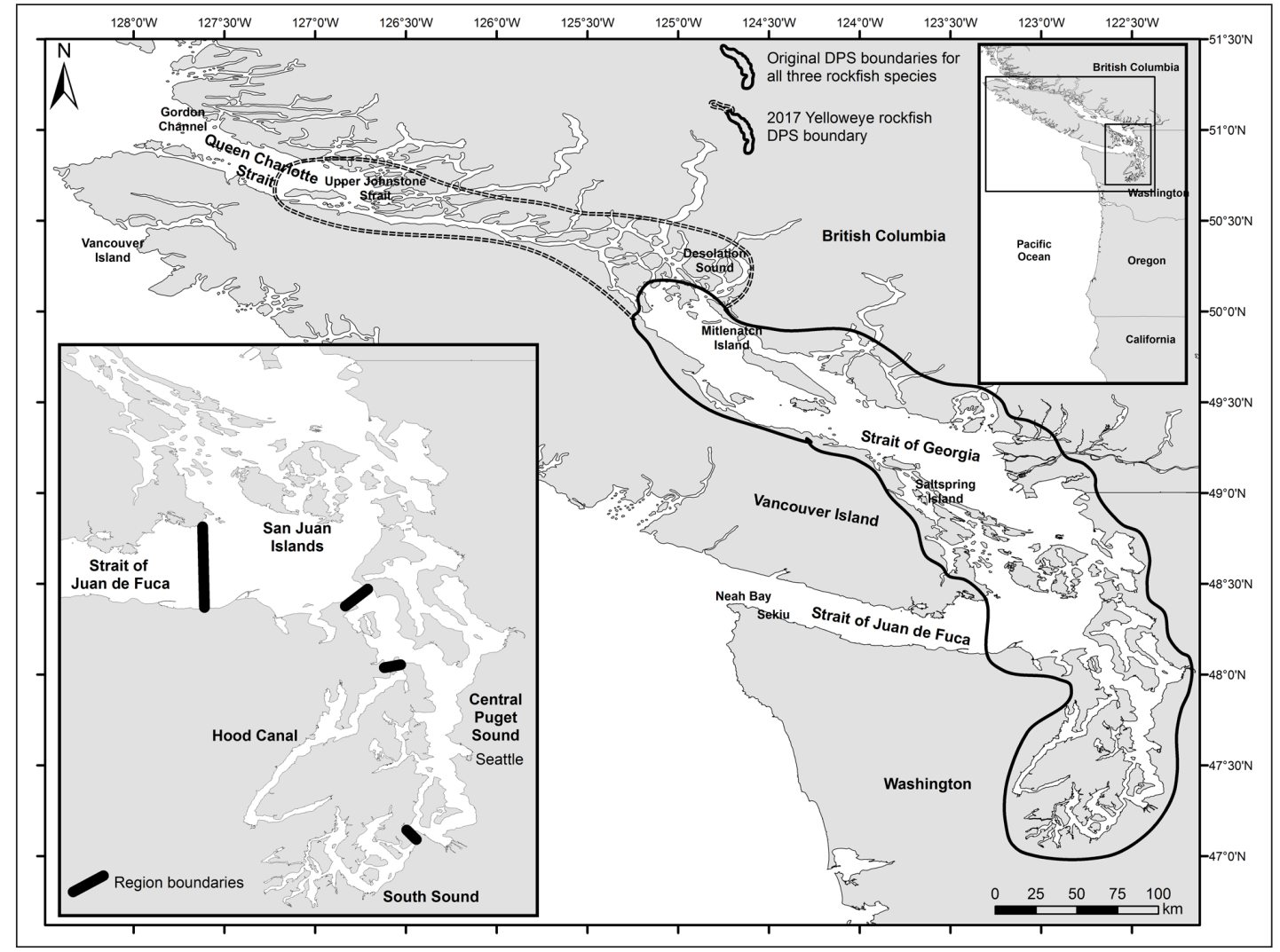

Figure 1: Map of the Puget Sound/Georgia Basin distinct population segment for each of three ESA-listed rockfish species in the original 2010 listing (solid line) and in the 2017 update for yelloweye rockfish (dashed line) and regions sampled (line breaks) with volunteer anglers for genetic analyses. 
logical Review Team that concluded: (1) the PSGB population of each species met the biological criteria of a listable unit as defined by the joint U.S. Fish \& Wildlife - NMFS interagency policy (USFWS-NMFS 1996); and (2) decreasing trends in abundance of rockfish in Puget Sound over the previous 50 years suggested moderate-to-high risk of extinction for these three species (Drake et al. 2010). The definition of a listable unit under the ESA includes taxonomically identified species and subspecies, as well as distinct population segments (DPS) (USFWS-NMFS 1996). Each rockfish species in this case was designated as a DPS, with their boundaries surrounding the Puget Sound/Georgia Basin region (Figure 1). However, most of the analyses supporting these designations were based on indirect evidence from other rockfish species in the region or from populations of target species outside the region because there was very little or no direct information available to evaluate the listing criteria for the three species in Puget Sound (Drake et al. 2010).

The ESA listings led to regulatory changes to both commercial and recreational fisheries in Puget Sound in 2010. Large-scale, non-tribal commercial fishing for rockfish and other bottom-dwelling fish peaked in the 1980s and dropped steeply in the 1990s following intense overfishing of rockfish and other species (Williams et al. 2010). With bans on bottom trawling in 1989, roller gear in 1991, and commercial jig and troll gear in 1992, essentially all non-tribal commercial fishing for rockfish in Puget Sound has been banned for the last 30 years (Williams et al. 2010; Tolimieri et al. 2017). However, six additional, relatively small-scale non-tribal commercial fisheries that encountered the listed rockfish species as bycatch were closed in 2010 (WDFW 2010). In the recreational fisheries, retaining yelloweye and canary rockfish had been banned since 2001, but when the ESA listings occurred, targeting, retaining, or possessing any rockfish species and recreationally fishing for other "bottomfish" deeper than 36.6 meters was prohibited within the geographical boundaries of the DPS in Washington State (WDFW 2015). Puget Sound is a fjordlike estuary with relatively steep shorelines and an average depth of 62.5 meters and a maximum depth of approximately 300 meters (NMFS 2007b); thus, the new restrictions applied to a considerably large proportion of the region. These management actions were all implemented to reduce direct and indirect mortality of the three ESA-listed rockfish species because these target fisheries occurred at similar depths and in similar habitats with the listed rockfish species. To manage each population effectively and to ensure that regulations do not put undo constraints on various user groups or human activities, it is important to have confidence in the listings and the geographical boundaries set for each species' DPS.

To increase our ability to successfully manage these populations and to reduce uncertainty in management decisions, new information needed to be collected from these species in Puget Sound. One efficient and cost-effective method to gather new information (Dickinson et al. 2010; Tulloch et al. 2013) and to determine what management actions will work best for recovery of these species is to engage and enlist the knowledge and expertise of the affected user and stakeholder groups (Enquist et al. 2017).

\section{Citizen engagement in cooperative research}

At the onset of the listings, the NMFS and the Washington Department of Fish \& Wildlife (WDFW) began a process to engage local user groups and stakeholders. This process began with a series of workshops, attended by local, state and federal wildlife managers and scientists and public user and stakeholder groups including the recreational fishing and SCUBA diving communities (NMFS 2017b). Research by academia, supported by NMFS, was then conducted to determine the key elements of successful citizen science/collaborative research programs (Browning 2013) and to understand how much the local recreational fishing community knew about rockfish populations in Puget Sound, their fishing practices and their preferences on potential recovery actions (Sawchuk et al. 2015). The results of these research projects (see "Education and Stewardship" below) were communicated broadly with user and stakeholder groups in the region, forming a basis for trust and working relationships between the management, scientific and stakeholder communities. As these relationships broadened over the next couple of years, motivated user-group leaders, managers and scientists met to brainstorm projects and secure funding that would fill some of the knowledge gaps related to rockfish in Puget Sound.

Combining the necessary sampling/experimental design practices of scientists with the historical knowledge and trade expertise of user groups allowed us to begin collecting new, reliable data for ESA-listed rockfish in Puget Sound. Volunteer anglers and SCUBA divers have successfully helped to collect specimens and data across four research projects to date. First, genetic samples of ESA-listed rockfish were collected to determine whether each species met criteria for being listed under the ESA. Second, yelloweye rockfish were targeted, collected and tagged with acoustic transmitters to monitor daily and seasonal movement patterns. Third, citizen scientist SCUBA surveys have begun to collect new data on the spatial and temporal distribution of young-of-year, juvenile and adult rockfish in nearshore habitats of Puget Sound. Preliminary investigations have shown that efforts to perform scientifically rigorous surveys among local dive club members in Puget Sound have increased each year (Figure 2A), and variation in the data collected appears to be decreasing over time (Figure 2B). Fourth, volunteer anglers are participating in a project targeting lingcod (Ophiodon elongatus), a species with an active recreational fishery which lives in similar habitats as protected rockfish, using different bait types to examine whether bycatch of rockfish can be limited in this fishery while maintaining adequate opportunities to fish for lingcod. Each project has been successful because of the local ecological knowledge and expertise of these groups.

The data collected from these research projects address multiple data gaps identified in the recovery plan for these species (NMFS 2017b) and will be tied together to inform future management decisions. Data collected by 


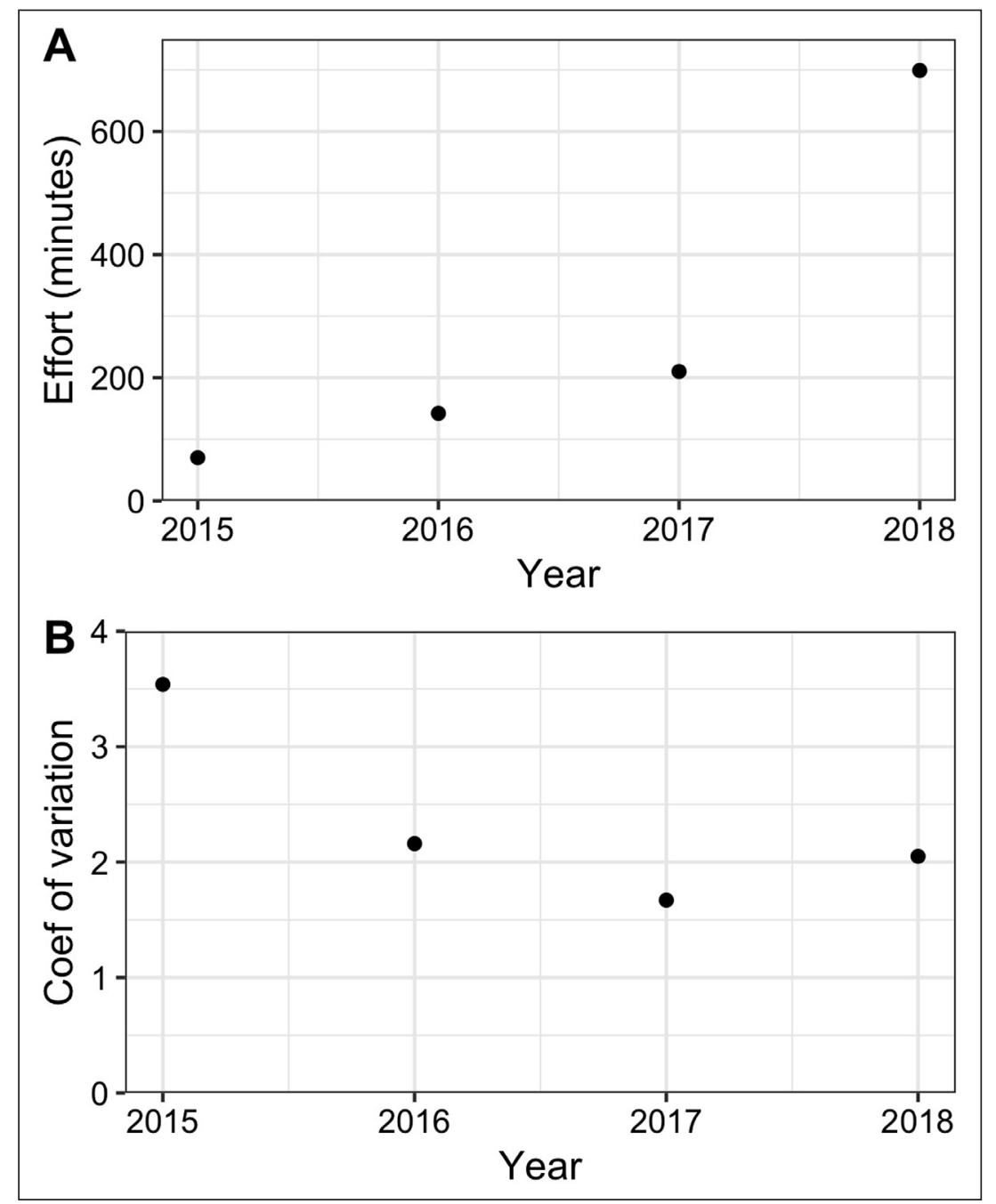

Figure 2: A) Sampling effort and B) coefficient of variation in data collected during citizen science SCUBA diving surveys for young-of-year, juvenile, and adult rockfish in Puget Sound.

volunteer SCUBA divers prior to and following the listing (REEF surveys; Pattengill-Semmens and Semmens 2003) were combined with formal scientific surveys by WDFW to estimate population trends for the initial listing process (Drake et al. 2010) and the five-year ESA review of the rockfishes listed in Puget Sound (NMFS 2016; Tolimieri et al. 2017). Data from the movement and bycatch studies are still being analyzed, so they have not been used in any management decisions to date, but were designed to address questions related to critical habitat designations and fisheries management strategies. These efforts will continue to help managers evaluate alternative management strategies and identify if/when recovery goals have been met for these populations. However, the most concrete example from this research program of citizen science being used to inform public policy comes from the genetics project examining whether these species meet the criteria of being listed under the ESA.

\section{Genetics of ESA-listed rockfish}

\section{Background}

The original 2010 listing process concluded that each of the three species qualified for listing under the ESA because they met the criteria of being a DPS. Two criteria must be met for a population to be designated a
DPS: (1) it must be "discrete" from other populations of the same species, and (2) it must be "significant" to the remainder of the species (USFWS-NMFS 1996). There was near unanimous support within the Biological Review Team for the "significance" criterion for each species based on the oceanographic and ecological isolation of the PSGB region, but there was significant uncertainty for the "discreteness" criterion (Drake et al. 2010).

Several factors can be used as evidence to determine whether a population is "discrete" from other populations of the same species, including marked differences in physical, physiological, ecological, morphological, behavioral and/or genetic characteristics (USFWS-NMFS 1996). In this case, geographical boundaries of Puget Sound and species-specific life history characteristics (e.g. adult/juvenile movement, timing and duration of larval dispersal, reproductive capacity, growth rates) were considered, but the final determination of discreteness relied heavily on indirect genetic evidence from other rockfish species and other fish taxa in Puget Sound because no genetic samples from the three species under review were available from Puget Sound. Of primary relevance was that genetic divergence had been found between Puget Sound and coastal populations for every other rockfish species that had been studied in this manner to date (e.g. Seeb 1998; 
Buonaccorsi et al. 2002; Buonaccorsi et al. 2005). The most direct evidence for the species of interest was a comparison that showed subtle differences in genetic structure between yelloweye rockfish populations just north of Puget Sound, in waters east and west of Vancouver Island, British Columbia (Figure 1; Yamanaka et al. 2006), which has subsequently been verified in a more recent study (Siegle et al. 2013). This research suggested that populations in the inland marine waters of British Columbia (i.e., east of Vancouver Island) may be isolated with respect to larval dispersal and adult movement from outer coast populations. However, no samples from US waters were included in this analysis to determine whether Puget Sound individuals also showed divergence from coastal individuals. Thus, there remained considerable uncertainty in the discreteness criterion for these three rockfish populations in the PSGB region. The primary objective of this project was to directly test whether individuals of the ESA-listed species in Puget Sound were genetically distinct from individuals of the same species collected on the outer coast.

\section{Methods}

We collaborated with state biologists at the WDFW, local charter boat captains and local recreational fishing clubs to collect genetic tissue samples from each species inside and outside the DPS (Andrews et al. 2018). Because these species occur in very low densities and live in complex, rocky habitats, routine sampling operations (e.g., bottom trawl surveys) were not capable of collecting enough individuals for adequate analysis, and trawling generally results in high mortality rates. Thus, we relied on the collective knowledge of the fishing and research communities and the trade expertise of volunteer anglers to locate and collect fish, respectively, for tissue samples from these rare species with comparably low direct mortality.

We began by collating known locations of each listed rockfish species from historical scientific and recreational fishing surveys. The greatest amount of data came from WDFW surveys of recreational fishermen; however, these data provided very general information - catch locations were identified by large marine areas without specific fishing sites and often, species were recorded only as "rockfish" instead of the exact species name. Direct observational data from WDFW, including bottom trawl, remotely operated vehicle, SCUBA diving, and drop-camera surveys, provided very specific density and location information, but these observations were limited in spatial and temporal distribution. Thus, to collect enough genetic samples from these species throughout the region, we needed a broader source of information.

We attended two local fishing club meetings to describe the planned research and to ask anglers to record their memories of where they had caught yelloweye rockfish, canary rockfish, and bocaccio by circling areas that they would fish on maps we brought to the meetings (Figure 3). This effort provided a baseline of potential locations to sample throughout Central Puget Sound, Hood Canal, the San Juan Islands, and the Strait of Juan de Fuca (Figure 1). Subsequently, other researchers shared information from their formal interviews of other scientific researchers in the region to identify and map "hot-spots" of rockfish populations (Antonelis et al. 2016).

Using historical locations from scientific surveys, maps from the club meetings, and shared information from the "hot-spot" interviews, we identified and selected sites based on the logistics of getting to these sites and the general likelihood of catching ESA-listed rockfish at the site. We used bathymetric maps of Puget Sound (Finlayson 2005) to determine the "likelihood" of a site being within appropriate depths $(\sim 30-100 \mathrm{~m})$ and with suitable complex habitat (e.g., narrow bathymetric lines) for these species. A site generally consisted of ocean bottom that was contiguously rocky and complex at the scale of approximately 300-700 meters of shoreline.

Using funding from the National Oceanic and Atmospheric Administration (NOAA) Cooperative Research Program, we engaged in a competitive bidding process to select recreational fishing charter captains and their vessels to use as a platform for each day of

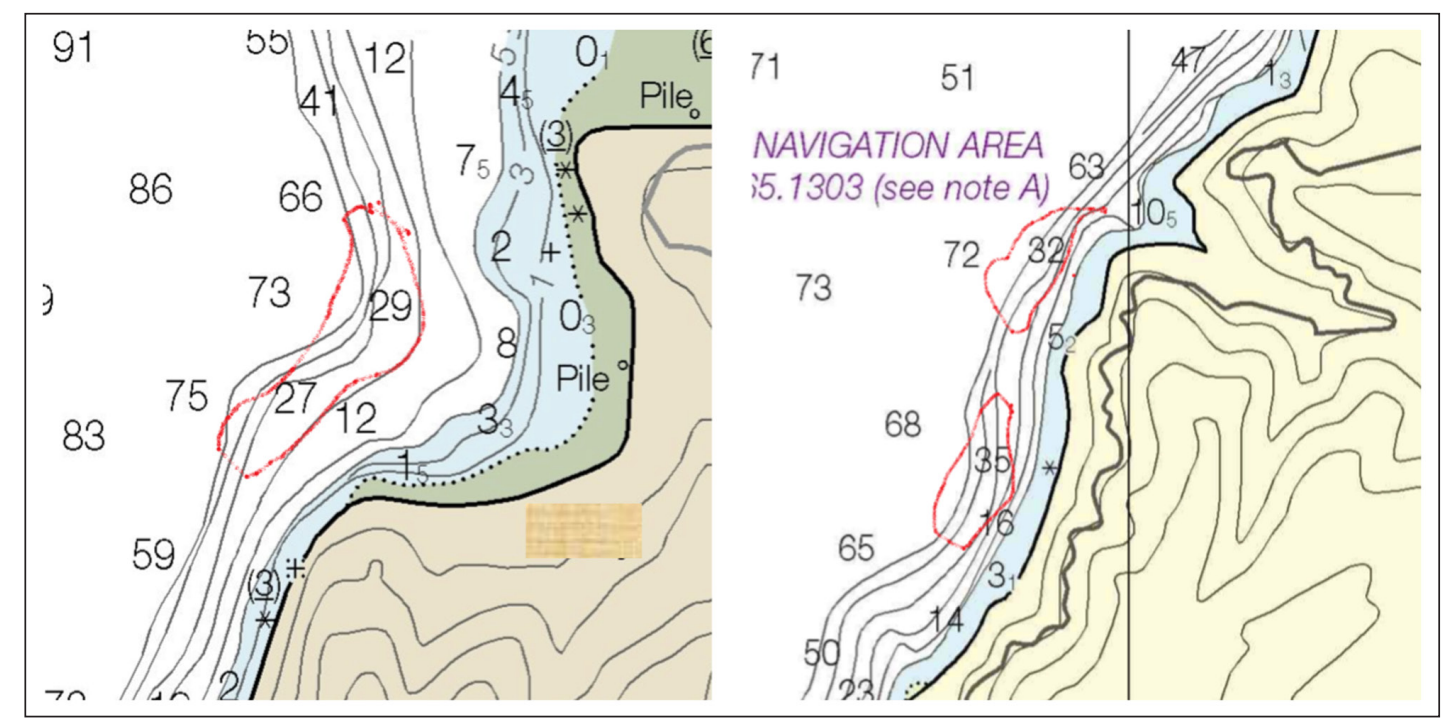

Figure 3: Example of maps showing locations where local anglers described where they used to fish for and catch ESA-listed rockfish. 
fishing/sampling across the five sampling regions. For each fishing day, we recruited volunteer anglers based on either a request-for-anglers email distributed by two fishing clubs (Puget Sound Anglers and the Kitsap Poggie Club) or through captain invites. We asked volunteers responding to the fishing club messages about their bottomfishing experience prior to inviting them out on the boat; this was important to ensure efficiency of fishing effort in complex, rocky bottom habitat, and was particularly used to select volunteers for days with more volunteers than could effectively fish on each boat. In addition to supplying sampling locations and their time and expertise volunteering to fish, anglers from the Puget Sound region provided recommendations for charter boat captains to hire as the platform for fishing and sampling. The selected charter boat captains provided expert guidance in how and when to fish for these species (e.g., best tidal and seasonal conditions) and were extremely engaged in a competition among themselves to see who could locate and capture more of these fish for the project. Moreover, several of the captains recruited more volunteer anglers whom they knew were very successful catching these species in the past.

With the captains piloting their vessel, volunteer anglers to catch fish, and one biologist on board to sample the catch, we fished for 73 days in five regions inside and outside Puget Sound (Figure 1) using common bottom hook-and-line fishing methods, including jigging hooks with bait (herring and squid) and artificial lures, to capture specimens at depths generally between 30 and 100 meters. For each fish collected, we recorded latitude and longitude of the boat, the bottom depth at the time of capture, fork length, weight, and sex (if visually distinguishable). A small tissue sample from the caudal fin was collected from each fish and stored in 95\% ethanol for subsequent genetic analyses.

The methods of the genetic analysis are described in detail in Andrews et al. (2018). Here, we present the results from one of those analyses, a principal components analysis. Briefly, this analysis reduces the amount of variation observed across thousands of regions of the genetic code among individual fish into two principal component axes that explain the most variation among individual fish. Each individual is plotted in two-dimensional space according to these two principal component values, and individuals closer to each other share similar variations in the genetic code, while individuals farther away from each other are more genetically distinct.

Formal estimates of catch-per-unit-effort were not calculated owing to the selective nature of our sampling design. We targeted sites of historical success, collected samples from a few individuals, and then moved to other sites to reduce bias in the genetic results that might occur by collecting large numbers of individuals from the same location.

Rockfish captured at these depths often incur barotrauma, injuries caused by the overexpansion of gases in the fish's swim bladder as pressure changes with depth, including eversion of the esophagus, bulging eyes, and air bubbles in the eyes and tissues (e.g., Parker et al. 2006;
Jarvis and Lowe 2008; Pribyl et al. 2009). When released at the surface, these fish generally do not have enough strength to overcome this extra buoyancy and cannot swim back down to the bottom on their own, thus becoming floating prey to birds and other predators. During our fishing trips, we used a Seaqualizer ${ }^{\circledR}$ descending device to release any rockfish that showed external signs of barotrauma that might keep them from being able to descend on their own. This device was attached to the line on a fishing rod or downrigger, then clipped to the fish's lip and sent to the ocean bottom with a heavy weight. At a specified depth, the clip opens up and releases the fish. By this time, the gases in the swim bladder have recompressed and the fish is able to make it the rest of the way to the bottom, thus minimizing indirect mortality caused by not being able to submerge on its own (Jarvis and Lowe 2008; Hochhalter and Reed 2011).

In addition to the samples collected during these fishing trips, we obtained fin clips of each species in regions outside of Puget Sound, captured in other monitoring programs conducted by various state and federal agencies in the United States and Canada (Andrews et al. 2018). The conditions set by the recreational fishing community's knowledge of previous fishing sites, bottom-fishing expertise by volunteer anglers, highly motivated captains, and an extremely collaborative scientific community provided the necessary framework for successful collection and gathering of adequate numbers of samples to answer our primary question.

\section{Results}

Over the course of the study, we sampled at 67 sites recommended by the research community based on historical locations taken from scientific surveys and answers from "hot-spot" interviews and 164 sites recommended by the recreational fishing community based on information gathered at club meetings, from the captains' input and from other volunteer anglers' memories (Figure 4). Most of the sites we sampled that were recommended by the fishing community were based on knowledge of the individual captains and volunteer anglers within each of the geographic regions that they generally fished in. Historical information from ROV surveys and science SCUBA diving surveys provided most of the sampling sites provided by the research community. Sites provided by the fishing community tripled the number of locations we were able to collect samples from for ESA-listed rockfish, but also resulted in fishing at 50 sites where we were caught zero fish $-30 \%$ of all fishing community sites.

We selected nine recreational fishing guides to provide their knowledge, expertise, and fishing vessel to sample across the five geographic regions and recruited 109 volunteer anglers to come out on the captain's vessels to target ESA-listed rockfish species. There were generally 2-4 volunteer anglers on each trip (Figure 5A), but certain captains preferred to fish as well as pilot the vessel at the same time, so the number of volunteers varied by day and by captain. All but one of the vessels were set up to fish most efficiently with 4 anglers fishing at one time, while one vessel was much larger and could efficiently 


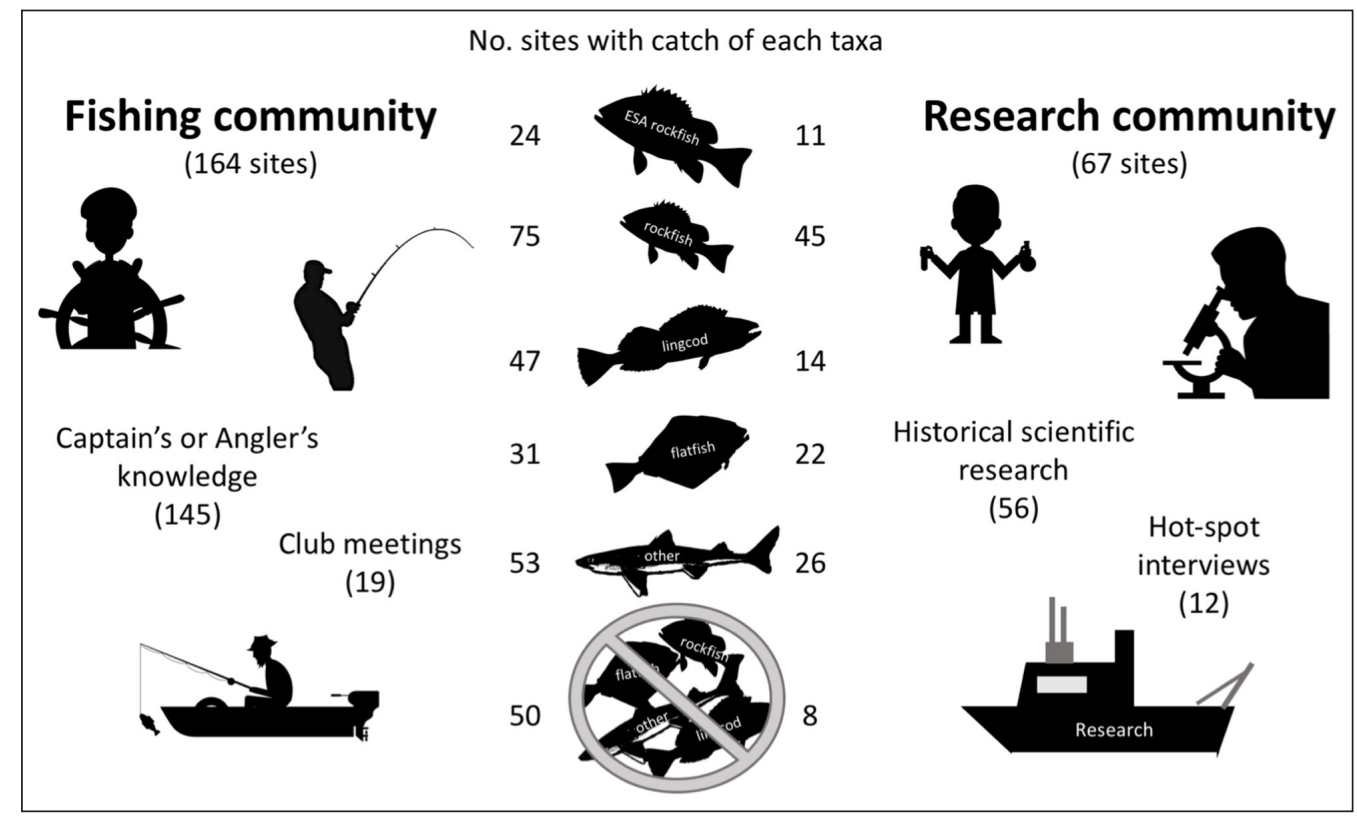

Figure 4: Summary of contributions by recreational fishing and research communities to site selection and number of sites with catch of major Puget Sound taxa categories during the population genetics study of ESA-listed rockfish in Puget Sound, WA, USA. Number of sites in each column will not add up to total number of sites due to multiple taxa being caught at the same sites.

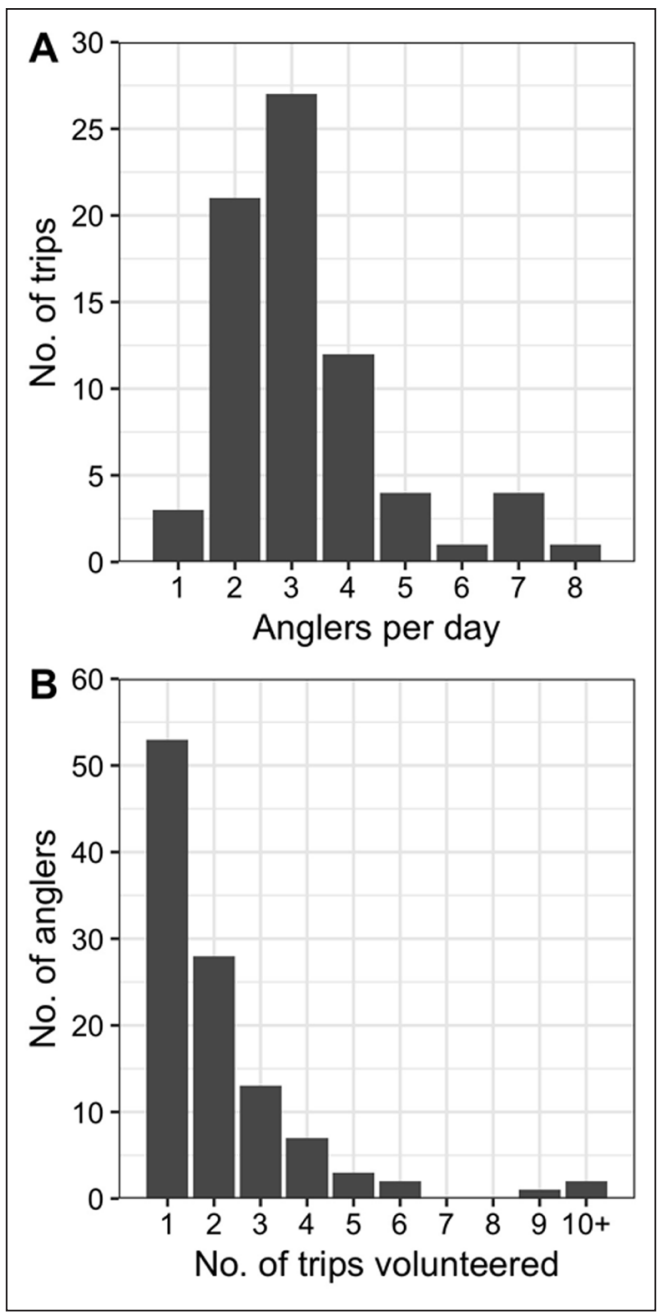

Figure 5: Number of $\mathbf{A}$ ) anglers per day and $\mathbf{B}$ ) fishing trips volunteered for by 109 volunteer anglers across 73 fishing trips across the five sampling regions. fish up to 8 anglers at one time. Eighty-one of the 109 volunteers came out on one or two fishing trips, but we also had three volunteers that came out on at least nine trips (Figure 5B).

We collected 1,676 bottomfish and took 1,111 genetic samples from fish of various taxa during these fishing trips. We collected a majority of four different fish taxa groups (Figure 6A) and ESA-listed rockfish (Figure 6B) at sites recommended by the recreational fishing community. More bocaccio and canary rockfish were caught and sampled at sites recommended by the research community, while the vast majority of yelloweye rockfish were caught and sampled at sites recommended by the fishing community (Figure 6C). One anecdote exemplifying the precision of the recreational fishing community's memories of good fishing locations was the collection of one of the three bocaccio. We fished at a site based on the 40-year-old childhood memory of a volunteer angler and located the "fishing hole" by triangulating the boat's position based on a road and a large rock located on shore during the first set at this site, we caught a bocaccio.

The genetic analyses using fish collected during these fishing trips showed two main results (Andrews et al. 2018). First, using principal components analysis (PCA) of the genetic data, we found that yelloweye rockfish collected inside and outside the DPS grouped into three genetic clusters (Figure 7A) - one cluster consisted of only individuals collected outside the DPS, the second cluster consisted of individuals collected from both inside and outside the DPS and the third cluster consisted of only individuals from the Hood Canal region within the DPS (with the exception of one individual). Looking more closely at the second cluster, the majority of individuals collected from outside the DPS were from sites further north in the inland waters of the Strait of Georgia, 

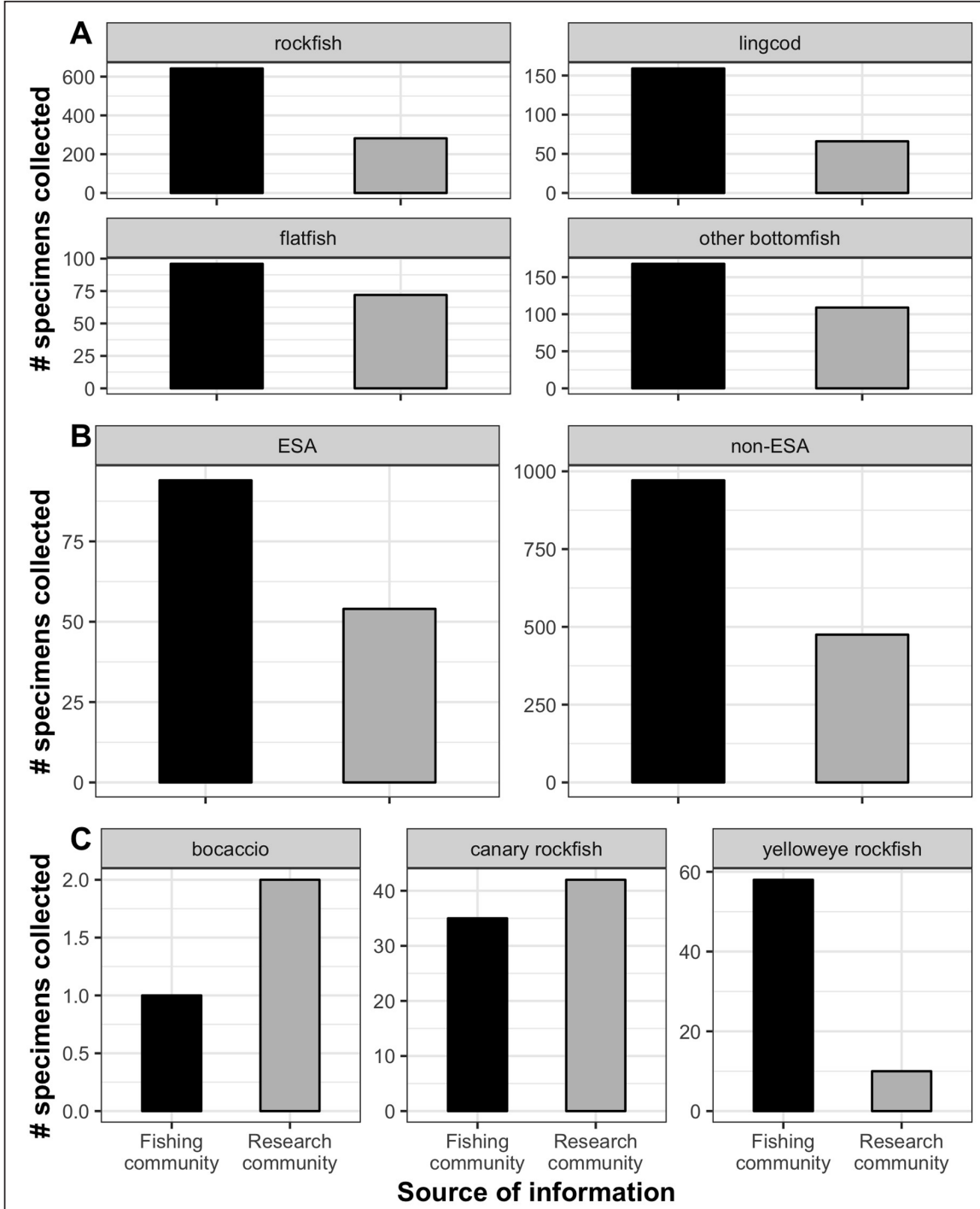

Figure 6: Number of fishes caught and sampled across A) four bottomfish taxa, B) ESA-listed and non-ESA-listed fish, and $\mathbf{C}$ ) individual ESA-listed rockfish species at sites recommended by the local recreational fishing or scientific research communities across the five geographic regions.

British Columbia, Canada (Desolation Sound and Upper Johnstone Strait; Figure 1). Thus, the PC1 axis separated yelloweye rockfish into coastal and inland-waters groups, while the PC2 axis separated Hood Canal yelloweye from other PSGB yelloweye (Figure 7A). Second, we found no evidence of population structure for canary rockfish among the regions sampled as seen by the complete overlapping of individuals from multiple regions (Figure 7B). The results from this PCA were confirmed by two other analytical approaches testing for population structure in each species (Andrews et al. 2018). We did not collect enough samples (3) to draw conclusions about stock structure of bocaccio. This may be due to bocaccio inhabiting more sandy/muddy habitats in deep water (>100 m), which were underrepresented in our sampling design due to efficiencies in sampling rocky habitats, which are preferred by the other two ESA-listed species. However, we continue to collaborate with the charter boat captains to collect fin clips, length data, and location information from any bocaccio that are incidentally caught during their normal business operations - this has resulted in one additional fin clip from this extremely rare species.

\section{Discussion}

The involvement, knowledge, and bottom fishing expertise of the recreational fishing community directly led to the collection of the necessary number of genetic samples from two of the three ESA-listed rockfish species. Moreover, we were able to obtain samples from a much larger number of sites than would have resulted from sampling only sites known to the scientific research community. This was critical to the interpretation of the scientific results because it provided confidence that the results were representative of the larger Puget Sound and Georgia Basin (in the case of yelloweye rockfish) regions and not just from a handful of geographic locations. Most of the volunteer anglers came out only once, but some participated on multiple days - this provided lots of opportunity for including stakeholders in the collection of scientific data while also allowing the expertise of certain volunteers to contribute efficiently to the collection of the necessary samples.

The results of the genetics project (Andrews et al. 2018) provided new, direct information regarding management of the ESA-listed rockfishes in Puget Sound. First, the new 


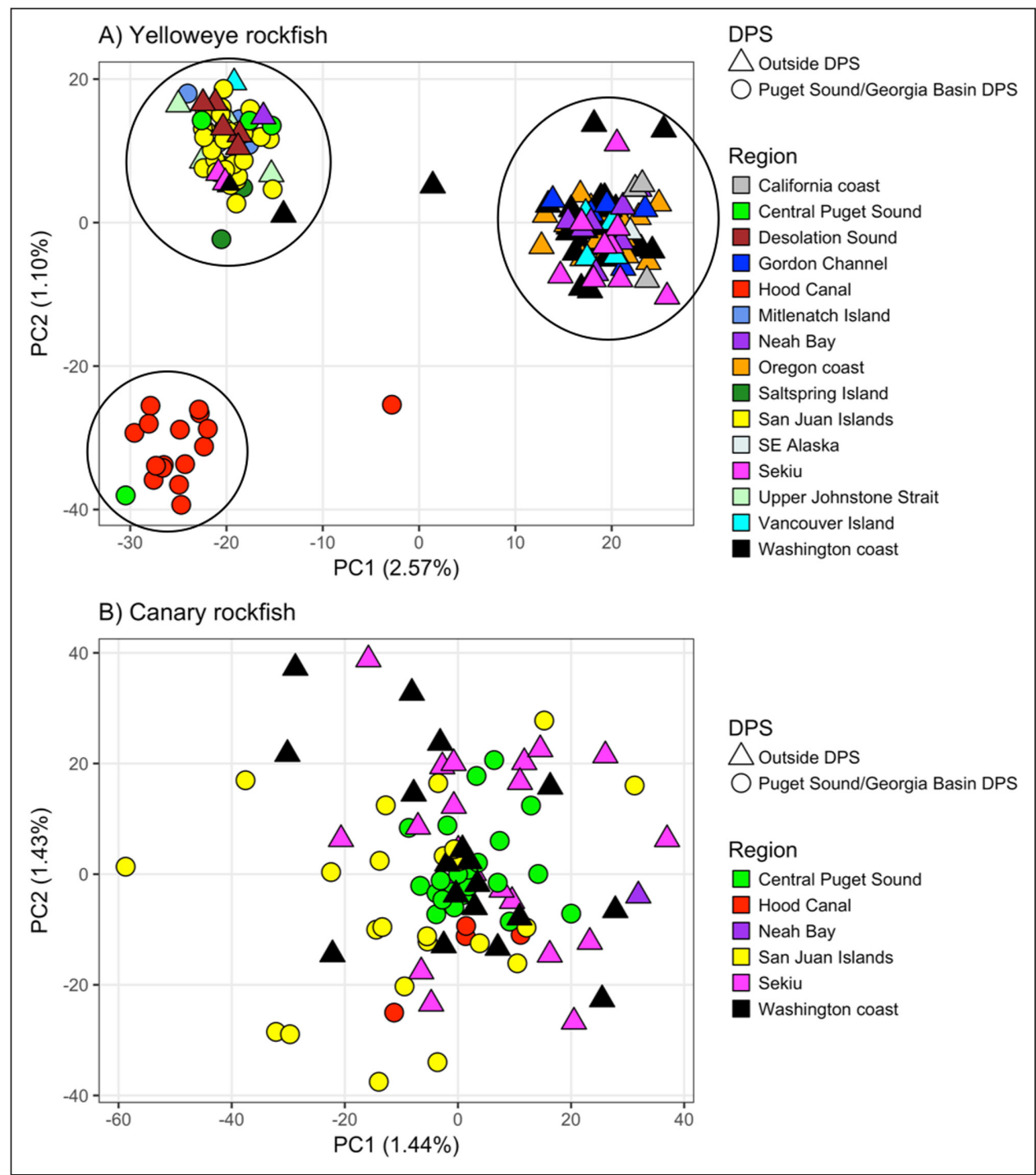

Figure 7: Principal components analysis reveals $\mathbf{A}$ ) three population clusters for yelloweye rockfish and $\mathbf{B}$ ) no population structure for canary rockfish across sampled geographic regions. Each symbol represents an individual fish from locations identified by shape and color of symbol. DPS: The original distinct population segment shown in Fig. 1. Reprinted by permission from Springer Nature: Conservation Genetics Andrews et al. 2018.

data and analyses supported the original listing decision that yelloweye rockfish in Puget Sound were discrete from coastal populations and met the first criterion of being a DPS. These analyses suggested limited connectivity between populations of yelloweye rockfish in the inland waters of Washington State and British Columbia and the outer coast population. Thus, if the PSGB population continues to decline, it is unlikely to be replenished by individuals from the outer coast and will continue to be at risk of extinction. Yelloweye rockfish are prone to overfishing: The population along the US west coast recently had its overfished status lifted but is still considered to be rebuilding because its biomass is below management goals (Gertseva and Cope 2018). Yelloweye rockfish in inland marine waters of British Columbia, Canada have been designated as a species of Special Concern (COSEWIC 2008) as the species was at $12 \%$ of unfished biomass in 2010 (Yamanaka et al. 2012), well below the $40 \%$ management reference point (DFO 2006). There are limited data on the population status and trends of yelloweye rockfish in the PSGB, and the analyses performed to date are based on inferences using overall rockfish abundance and assemblage structure (Drake et al. 2010; Tolimieri et al. 2017), but collecting these data is one of the key research priorities of the recovery plan (NMFS 2017b). Clearly, successful management and conservation of yelloweye rockfish in the inland marine waters of the PSGB should include coordinated international efforts between the US and Canada.

Second, the new data and analyses showed that canary rockfish collected in Puget Sound were not genetically differentiated from the canary rockfish collected on the outer coast, and suggested that they may not meet the first criterion of being designated as a DPS. The genetic similarities across inland and coastal regions for canary rockfish suggest a relatively sufficient level of connectivity, due to adult movement or larval dispersal. Thus, even with low numbers of canary rockfish in the PSGB region, it appears likely that replenishment from a healthy coastal population can occur during years of good environmental and reproductive conditions. The canary rockfish stock on the outer coast of the US was declared overfished in 2000 , but was declared rebuilt in 2015 (PFMC 2015). 


\section{Public policy decision-making}

Citizen science has contributed in many instances to research and recovery planning related to protected species. Volunteer birders, for example, provide a wealth of data on abundance and distribution of birds, leading to enhanced federal protection of some declining populations (Hudson et al. 2017) and information on the nonmarket value associated with biodiverse locations and sightings of endangered species (Kolstoe and Cameron 2017). Citizen scientists have collected decades of data on the abundance and migration timing of Eastern North Pacific gray whales (Eschrichtius robustus). The data come from sighting locations that are suboptimal for population census, and thus were not used in the decision to delist gray whales from the Endangered Species List in 1994; however, the data provide helpful information on migration timing, seasonal behavior, calf numbers, and whalehuman interactions to federal researchers and managers (Rugh et al. 1999). Similarly, homeowners in southern Arizona provided data on age, size, sex, and feeding behavior of lesser long-nosed bats (Leptonycteris yerbabuenae) that appeared at hummingbird feeders; these bats were delisted in 2018, and although the citizen science data could not be used for population determinations, they nevertheless provided helpful and previously unavailable information on the bat's life history and patterns of habitat use (USFWS 2016). A more analogous effort to ours followed the delisting of gray wolves (Canis lupus) under the ESA in 2012: Regulated hunting of wolves resumed after that decision, and genetic information derived from muscle tissues provided by hunters in Minnesota indicated that wolf population structure changed and migration distances decreased in the years immediately after hunting resumed (Rick et al. 2017). Clearly, citizen science can provide valuable information for the conservation and management of threatened and endangered species. The information provided by lethal (or non-lethal) tissue sampling can be especially valuable given the importance of population structure in ESA listing determinations and the advances in genetics research; thus, partnerships between researchers, managers, and stakeholders such as anglers or hunters present important opportunities.

In our study, the new genetic analyses derived from the collaboration with recreational anglers and charter captains were presented to NOAA's original Biological Review Team (BRT) during the mandatory five-year review update for ESA-listed species in November 2015 (NMFS 2016). Upon reviewing this information, the BRT provided two main conclusions to the Protected Resources Division of NOAA's West Coast Regional Office: (1) the new genetic information supported the previous conclusion that yelloweye rockfish from the PSGB are discrete from coastal populations, but that the northern boundary of the yelloweye rockfish DPS appeared to be farther north in the Queen Charlotte Strait rather than at the originally designated boundary at the northern Strait of Georgia (Figure 1); and (2) the new genetic information indicated that canary rockfish in the PSGB were not discrete and are likely part of a DPS that also includes populations on the outer coast.
Based on these conclusions, known life-history characteristics and new information from other sources since 2010 (e.g. Siegle et al. 2013), the NMFS wrote a draft ruling to (i) affirm the existence of and amend the DPS boundaries for yelloweye rockfish, and (ii) delist canary rockfish from the ESA. This ruling went through a period of external scientific peer review, public comment and responses to those reviews and comments. After consideration of all information available, the proposed ruling was made final on March 24, 2017 (NMFS 2017a) resulting in a shift in the DPS boundaries for yelloweye rockfish and the delisting of canary rockfish.

The decision-making process in this case study is a good example of the way that the best available science led to an adaptive response by federal managers. Importantly, the angler surveys, genetics, movement, bycatch and SCUBA diving research projects in Puget Sound have provided a platform for the integration of formal science practices and the wealth of local ecological knowledge of user and stakeholder groups. These characteristics led to the collection of new data that resulted in new management decisions, including the first de-listing of a marine fish species under the ESA. Having a highly engaged stakeholder and scientific community working on the water closely together was essential for collecting the number of samples required to complete a statistically robust genetic analysis (Andrews et al. 2018), and to do so in a way that minimized handling mortality of these rare and protected species. Moreover, the collaboration fostered high levels of trust and commitment that helped guide the decisionmaking process (Enquist et al. 2017).

\section{Education and stewardship}

In addition to the two public policy decisions resulting from the new data collections, a second mission for NMFS is to enhance public awareness, education, and stewardship of our marine resources. Including public volunteers in the data collection process provided an opportunity for two-way education between scientists and the public. One of the most asked questions by volunteer anglers on these fishing trips was "How old is that fish?" Rockfish are generally long-lived, slow-growing and slow-to-mature species (Love et al. 2002). Previous research found that $42 \%$ of recreational anglers surveyed in Puget Sound did not know that rockfish are long-lived, yet anglers who reported knowledge of rockfish longevity were more likely to perceive rockfish as threatened and to support recovery measures (Sawchuk et al. 2015). When a 43-cm yelloweye rockfish was caught and scientists explained that fish could be anywhere from 10-80 years old (Andrews et al. 2002) and have a 50 percent chance of being mature (Gertseva and Cope 2017), anglers immediately understood that these rockfish species are vulnerable and will have a difficult time recovering if they are overfished. On the other side, the tales of fishing with parents, siblings and friends told by anglers made it immediately clear to the scientists and managers what fishing means to the community and the lengths to which they are willing to go to help ensure the sustainability of the resource. 
Finally, through this partnership, the recreational anglers are becoming leaders in community-level rockfish conservation through the use of descender devices. During our research fishing trips, we used descending devices to return rockfish back to their bottom habitat if they showed signs of barotrauma. Using these devices elicited positive responses from the captains and volunteer anglers. Anglers shared many stories of having to release rockfish (due to no-take regulations) that were bloated and seeing them float away, unable to swim down under their own strength. As part of this cooperative research program, local fishing clubs have secured funding for, purchased, and handed out descending devices to the public at boat launches and meetings to reduce indirect mortality of these species and to prevent closure of other fisheries. With the support of fishing clubs such as Puget Sound Anglers, the state of Washington now requires the use of descending devices in recreational bottomfish fisheries to release rockfish at depth. Using descending devices also has become codified within the halibut fishery inside the DPS (NMFS 2018) and on the outer coast within the Pacific Fisheries Management Council's regulations, whereby the recreational fishery receives "survival credits" for descending rockfish species (e.g., Bellman et al. 2013). Exposure to these new technologies during collaborative research has helped to promote conservation of rockfish, reduce bycatch mortality, and begun to increase fishing opportunities that once were lost. All of these "on the water" moments have created lasting, meaningful memories, enhanced trust within the recreational fishing community of the scientific findings, a foundation for continued collaboration, and a strong sense of why stewardship of our natural resources is every citizen's responsibility.

\section{Conclusion}

The ESA listing of three rockfish species in Puget Sound provided an opportunity for the scientific and stakeholder communities to form a working relationship with a common goal - recovery and delisting of ESA-listed rockfish. This relationship has led to the development of research projects and the collection of much-needed new information that has provided the basis for new public policy rulings on threatened rockfish species. This is a great example of an adaptive management response to the original uncertainty in scientific advice and the subsequent decision-making process based on that advice (Kelly et al. 2017). Notably, the scientific analyses responsible for these updated decisions were based on new information gained, in large part, as a result of knowledge and expertise of citizen scientists in the recreational fishing community. In times of limited funding for natural resource management and scientific inquiry, it is crucial to take advantage of all sources of knowledge and expertise available to fill the gaps needed to answer management-relevant questions. Other projects employing the knowledge and expertise of the fishing and SCUBA diving communities of Puget Sound will continue to be incorporated into the framework for monitoring and assessing the recovery of the remaining two ESA-listed rockfish species in Puget Sound.

\section{Data Accessibility Statement}

The raw genetic sequencing data are available via National Center for Biotechnology Information at https://www.ncbi.nlm.nih.gov/bioproject/PRJNA451040 and the summarized data are available here: https:// static-content.springer.com/esm/art\%3A $10.1007 \%$ 2Fs10592-018-1060-0/MediaObjects/10592_2018_1060_ MOESM1_ESM.xlsx.

\section{Acknowledgements}

We thank the captains and volunteer anglers who provided their time, expertise, and knowledge of fish populations throughout the Puget Sound region; citizen science SCUBA divers for performing visual surveys underwater; and the Washington Department of Fish \& Wildlife, University of Washington, Department of Fisheries and Oceans Canada, the Fishery Resource Analysis and Monitoring Division at the Northwest Fisheries Science Center, and the Fisheries Ecology Division at the Southwest Fisheries Science Center for sharing locations and samples of ESA-listed rockfish from their surveys. We also thank Su Kim for the silhouette images in the figures.

\section{Funding Information}

The research described here was permitted under ESA Section 10a permit \#17062-3M and funded primarily through the National Oceanic \& Atmospheric Administration's Cooperative Research Program in 2014. The scientific results and conclusions, as well as any views or opinions expressed herein, are those of the authors and do not necessarily reflect the views of the National Oceanic \& Atmospheric Administration or the US Department of Commerce.

\section{Competing Interests}

The authors have no competing interests to declare.

\section{References}

Anadón, JD, Giménez, A, Ballestar, R and Pérez, I. 2009. Evaluation of local ecological knowledge as a method for collecting extensive data on animal abundance. Conservation biology, 23: 617-625. DOI: https://doi.org/10.1111/j.1523-1739.2008.01145.x

Andrews, AH, Cailliet, GM, Coale, KH, Munk, KM, Mahoney, MM and O'Connell, VM. 2002. Radiometric age validation of the yelloweye rockfish (Sebastes ruberrimus) from southeastern Alaska. Marine and Freshwater Research, 53: 139-146. DOI: https://doi. org/10.1071/MF01126

Andrews, KS, Nichols, KM, Elz, A, Tolimieri, N, Harvey, CJ, Pacunski, R, Lowry, D, Yamanaka, KL and Tonnes, DM. 2018. Cooperative research sheds light on population structure and listing status of threatened and endangered rockfish species. Conservation Genetics, 19: 865-878. DOI: https://doi.org/10.1007/ s10592-018-1060-0

Antonelis, K, Drinkwin, J, Rudell, P and Shipley, M. 2016. Identifying rockfish hot spot areas in Puget Sound through a spatial analysis of "grey" data. Seattle, WA: Natural Resources Consultants, Inc. 
Azzurro, E, Moschella, P and Maynou, F. 2011. Tracking signals of change in Mediterranean fish diversity based on local ecological knowledge. PLoS One, 6: e24885. DOI: https://doi.org/10.1371/journal. pone.0024885

Bastari, A, Beccacece, J, Ferretti, F, Micheli, F and Cerrano, C. 2017. Local ecological knowledge indicates temporal trends of benthic invertebrates species of the Adriatic Sea. Frontiers in Marine Science, 4: 157. DOI: https://doi.org/10.3389/fmars.2017.00157

Beaudreau, AH and Levin, PS. 2014. Advancing the use of local ecological knowledge for assessing data-poor species in coastal ecosystems. Ecological Applications, 24: 244-256. DOI: https://doi.org/10.1890/13-0817.1

Bellman, MA, Jannot, J, Mandrup, M and McVeigh, J. 2013. Estimated discard and catch of groundfish species in the 2012 U.S. west coast fisheries. NOAA Fisheries. NWFSC Observer Program, 2725. Montlake Blvd E., Seattle, WA 98112.

Bland, L and Collen, B. 2016. Species loss: lack of data leaves a gap. Nature, 537: 488. DOI: https://doi. org/10.1038/537488c

Bland, LM, Bielby, J, Kearney, S, Orme, CDL, Watson, JE and Collen, B. 2017. Toward reassessing data-deficient species. Conservation Biology, 31: 531-539. DOI: https://doi.org/10.1111/cobi.12850

Bonney, R, Cooper, CB, Dickinson, J, Kelling, S, Phillips, T, Rosenberg, KV and Shirk, J. 2009. Citizen science: a developing tool for expanding science knowledge and scientific literacy. BioScience, 59: 977-984. DOI: https://doi.org/10.1525/ bio.2009.59.11.9

Browning, H. 2013. Final Report for Rockfish Cooperative Research Assessment: The benefits, structure and principles of cooperative research: A guide for the development of projects in Puget Sound supporting rockfish recovery. Accessed September 19, 2018: https://www. westcoast.fisheries.noaa.gov/publications/protected_ species/other/rockfish/final_report_noaa_rockfish_ cooperative_research_assmt_aug_2013.pdf.

Buonaccorsi, VP, Kimbrell, CA, Lynn, EA and Vetter, RD. 2002. Population structure of copper rockfish (Sebastes caurinus) reflects postglacial colonization and contemporary patterns of larval dispersal. Canadian Journal of Fisheries and Aquatic Sciences, 59: 1374-1384. DOI: https://doi.org/10.1139/f02-101

Buonaccorsi, VP, Kimbrell, CA, Lynn, EA and Vetter, RD. 2005. Limited realized dispersal and introgressive hybridization influence genetic structure and conservation strategies for brown rockfish, Sebastes auriculatus. Conservation Genetics, 6: 697-713. DOI: https:// doi.org/10.1007/s10592-005-9029-1

COSEWIC. 2008. COSEWIC assessment and status report on the Yelloweye Rockfish Sebastes ruberrimus, Pacific Ocean inside waters population and Pacific Ocean outside waters population, in Canada. Committee on the Status of Endangered Wildlife in Canada, vii: 75. Ottawa.

DFO. 2006. A harvest strategy compliant with a precautionary approach. p. 7, DFO Canadian Science Advisory Secretariat Science Advisory Report 2006/023.
Dickinson, JL, Zuckerberg, B and Bonter, DN. 2010. Citizen science as an ecological research tool: challenges and benefits. Annual review of ecology, evolution, and systematics, 41: 149-172. DOI: https://doi. org/10.1146/annurev-ecolsys-102209-144636

Doremus, H. 2008. Data gaps in natural resource management: sniffing for leaks along the information pipeline. Indiana Law Journal, 83: 407.

Drake, JS, Berntson, EA, Gustafson, RG, Holmes, EE, Levin, PS, Tolimieri, N, Waples, RS, Sogard, SM, Williams, GD and Cope, JM. 2010. Status review of five rockfish species in Puget Sound, Washington: Bocaccio (Sebastes paucispinis), canary rockfish (S. pinniger), yelloweye rockfish (S. ruberrimus), greenstriped rockfish (S. elongatus), and redstripe rockfish (S. proriger). US Department of Commerce, National Oceanic and Atmospheric Administration, National Marine Fisheries Service.

Enquist, CA, Jackson, ST, Garfin, GM, Davis, FW, Gerber, LR, Littell, JA, Tank, JL, Terando, AJ, Wall, TU and Halpern, B. 2017. Foundations of translational ecology. Frontiers in Ecology and the Environment, 15: 541-550. DOI: https://doi.org/10.1002/fee.1733

Finlayson, D. 2005. Combined bathymetry and topography of the Puget Lowland, Washington State, University of Washington.

Gertseva, V and Cope, JM. 2017. Stock assessment of the yelloweye rockfish (Sebastes ruberrimus) in state and Federal waters off California, Oregon and Washington. Portland, OR: Pacific Fishery Management Council. Available from http://www.pcouncil.org/groundfish/ stock-assessments/.

Gertseva, V and Cope, JM. 2018. Rebuilding analysis for yelloweye rockfish (Sebastes ruberrimus) based on the 2017 stock assessment. Portland, OR: Pacific Fishery Management Council. Available from http://www. pcouncil.org/groundfish/stock-assessments/.

Harris, JBC, Reid, JL, Scheffers, BR, Wanger, TC, Sodhi, NS, Fordham, DA and Brook, BW. 2012. Conserving imperiled species: a comparison of the IUCN Red List and US Endangered Species Act. Conservation Letters, 5: 64-72. DOI: https://doi.org/10.1111/ j.1755-263X.2011.00205.x

Hochhalter, SJ and Reed, DJ. 2011. The effectiveness of deepwater release at improving the survival of discarded yelloweye rockfish. North American Journal of Fisheries Management, 31: 852-860. DOI: https://doi. org/10.1080/02755947.2011.629718

Holling, CS. 1978. Adaptive environmental assessment and management. John Wiley \& Sons.

Hudson, MAR, Francis, CM, Campbell, KJ, Downes, CM, Smith, AC and Pardieck, KL. 2017. The role of the North American Breeding Bird Survey in conservation. The Condor: Ornithological Applications, 119: 526-545. DOI: https://doi.org/10.1650/CONDOR-17-62.1

Huntington, HP. 2000. Using traditional ecological knowledge in science: methods and applications. Ecological applications, 10: 1270-1274. DOI: https://doi. org/10.1890/1051-0761(2000)010[1270:UTEKIS]2.0 $\mathrm{CO} ; 2$ 
IUCN. 2018. The IUCN Red List of Threatened Species. Version 2018-1. Accessed 05 July 2018: http://www. iucnredlist.org.

Jarvis, ET and Lowe, CG. 2008. The effects of barotrauma on the catch-and-release survival of southern California nearshore and shelf rockfish (Scorpaenidae, Sebastes spp.). Canadian Journal of Fisheries and Aquatic Sciences, 65: 1286-1296. DOI: https://doi. org/10.1139/F08-071

Kelly, RP, Levin, PS and Lee, KN. 2017. Science, policy, and data-driven decisions in a data vacuum. Ecology Law Quarterly, 44: 7-40.

Kolstoe, S and Cameron, TA. 2017. The non-market value of birding sites and the marginal value of additional species: biodiversity in a random utility model of site choice by eBird members. Ecological economics, 137: 1-12. DOI: https://doi.org/10.1016/j. ecolecon.2017.02.013

Lee, KN. 1993. Compass and gyroscope: integrating science and politics for the environment. Island Press.

Love, MS, Yoklavich, M and Thorsteinson, L. 2002. The rockfishes of the northeast Pacific. Berkeley: University of California Press.

Murphy, DD and Weiland, PS. 2014. Science and structured decision making: fulfilling the promise of adaptive management for imperiled species. Journal of Environmental Studies and Sciences, 4: 200-207. DOI: https://doi.org/10.1007/s13412-014-0165-0

NMFS. 2007a. Listing endangered and threatened species and designating critical habitat: Petition to list copper and quillback rockfishes in Puget Sound (Washington) as threatened species under the Endangered Species Act. Docket No. 070108002-7002-01. National Marine Fisheries Service, National Oceanic and Atmospheric Administration, Department of Commerce.

NMFS. 2007b. Sound Science: Synthesizing ecological and socioeconomic information about the Puget Sound ecosystem. Ruckelshaus, MH, McClure, MM (coordinators); prepared in cooperation with the Sound Science collaborative team. U.S. Dept. Commerce, National Oceanic and Atmospheric Administration (NMFS), Northwest Fisheries Science Center. Seattle, Washington. 93 p.

NMFS. 2010. Endangered and threatened wildlife and plants: threatened status for the Puget Sound/Georgia Basin distinct population segments of yelloweye and canary rockfish and endangered status for the Puget Sound/Georgia Basin distinct population segment of bocaccio rockfish. National Marine Fisheries Service, Federal Register 75 FR 22276.

NMFS. 2016. 5-Year Review: Yelloweye Rockfish, Canary Rockfish, and Bocaccio of the Puget Sound/Georgia Basin. National Oceanic \& Atmospheric Administration, National Marine Fisheries Service, West Coast Region, Office of Protected Resources, Seattle, WA. $131 \mathrm{p}$.

NMFS. 2017a. Endangered and threatened species; removal of the Puget Sound/Georgia Basin distinct population segment of canary rockfish from the federal list of threatened and endangered species and removal of designated critical habitat, and update and amendment to the listing descriptions for the yelloweye rockfish DPS and bocaccio DPS. Docket No. 160524463-7001-02. National Marine Fisheries Service, National Oceanic and Atmospheric Administration, Department of Commerce.

NMFS. 2017b. Rockfish Recovery Plan: Puget Sound/Georgia Basin yelloweye rockfish (Sebastes ruberrimus) and bocaccio (Sebastes paucispinis). Seattle, WA: National Marine Fisheries Service.

NMFS. 2018. National Marine Fisheries Service Endangered Species Act (ESA) Section 7(a)(2) Biological Opinion and Magnuson-Stevens Act Essential Fish Habitat (EFH): Consultation on the implementation of the Area 2A (U.S. West Coast) Pacific halibut catch sharing plan. NMFS Consultation Number: WCR2017-8426.

Parker, SJ, McElderry, HI, Rankin, PS and Hannah, RW. 2006. Buoyancy regulation and barotrauma in two species of nearshore rockfish. Transactions of the American Fisheries Society, 135: 1213-1223. DOI: https://doi.org/10.1577/T06-014.1

Pattengill-Semmens, CV and Semmens, BX. 2003. Conservation and management applications of the reef volunteer fish monitoring program. In: Coastal Monitoring through Partnerships. Springer, 43-50. DOI: https://doi.org/10.1007/978-94-017-0299-7_5

PFMC. 2015. Pacific Fishery Management Council News Release: West Coast groundfish stocks improve. Accessed October 5, 2018: http://www.pcouncil.org/ wp-content/uploads/2016/07/Petrale-canary-pressrelease.pdf.

Pribyl, AL, Schreck, CB, Kent, ML and Parker, SJ. 2009. The Differential Response to Decompression in Three Species of Nearshore Pacific Rockfish. North American Journal of Fisheries Management, 29: 1479-1486. DOI: https://doi.org/10.1577/M08-234.1

Rick, JA, Moen, RA, Erb, JD and Strasburg, JL. 2017. Population structure and gene flow in a newly harvested gray wolf (Canis lupus) population. Conservation Genetics, 18: 1091-1104. DOI: https://doi. org/10.1007/s10592-017-0961-7

Rugh, DJ, Muto, MM, Moore, SE and DeMaster, DP. 1999. Status review of the Eastern North Pacific stock of gray whales. U.S. Dept. of Commerce: NOAA Tech. Memo. NMFS-AFSC-103. 93 p.

Sawchuk, JH, Beaudreau, AH, Tonnes, D and Fluharty, D. 2015. Using stakeholder engagement to inform endangered species management and improve conservation. Marine Policy, 54: 98-107. DOI: https:// doi.org/10.1016/j.marpol.2014.12.014

Seeb, LW. 1998. Gene flow and introgression within and among three species of rockfishes, Sebastes auriculatus, S. caurinus, and S. maliger. Journal of Heredity, 89: 393-403. DOI: https://doi.org/10.1093/ jhered/89.5.393

Siegle, MR, Taylor, EB, Miller, KM, Withler, RE and Yamanaka, KL. 2013. Subtle population genetic structure in yelloweye rockfish (Sebastes ruberrimus) is consistent with a major oceanographic division in British Columbia, Canada. PLoS One, 8: e71083. DOI: https://doi.org/10.1371/journal.pone.0071083 
Sutherland, WJ, Pullin, AS, Dolman, PM and Knight, TM. 2004. The need for evidence-based conservation. Trends in ecology \& evolution, 19: 305-308. DOI: https://doi.org/10.1016/j.tree.2004.03.018

Tolimieri, N, Holmes, EE, Williams, GD, Pacunski, R and Lowry, D. 2017. Population assessment using multivariate time-series analysis: A case study of rockfishes in Puget Sound. Ecology and evolution, 7: 2846-2860. DOI: https://doi.org/10.1002/ece3.2901

Tulloch, AI, Possingham, HP, Joseph, LN, Szabo, J and Martin, TG. 2013. Realising the full potential of citizen science monitoring programs. Biological Conservation, 165: 128-138. DOI: https://doi.org/10.1016/j. biocon.2013.05.025

USFWS. 2016. Species status assessment for the lesser long-nosed bat (Leptonycteris yerbabuenae). Albuquerque, NM: U.S. Fish and Wildlife Service, Southwest Region. 96 p.

USFWS-NMFS. 1996. Policy regarding the recognition of distinct vertebrate population segments under the Endangered Species Act. Federal Register, 61(26): 4721-4725.

Walters, CJ. 1986. Adaptive management of renewable resources. Macmillan Publishers Ltd.
WDFW. 2010. Rule-making order, CR-103e, emergency rule closing several commercial fisheries in Puget Sound. Order No. 10-191. Washington State Department of Fish \& Wildlife.

WDFW. 2015. Washington Sport Fishing Rules. Washington Department of Fish and Wildlife. http:// wdfw.wa.gov/fishing/regulations/. Accessed 29 March 2016.

Williams, GD, Levin, PS and Palsson, WA. 2010. Rockfish in Puget Sound: An ecological history of exploitation. Marine Policy, 34: 1010-1020. DOI: https://doi. org/10.1016/j.marpol.2010.02.008

Yamanaka, KL, Lacko, LC, Withler, R, Grandin, C, Lochead, JK, Martin, JC, Olsen, $\mathbf{N}$ and Wallace, SS. 2006. A review of yelloweye rockfish Sebastes ruberrimus along the Pacific coast of Canada: biology, distribution and abundance trends. p. 54. Canadian Science Advisory Secretariat Research Document.

Yamanaka, KL, McAllister, MK, Olesiuk, PF, Etienne, MP, Obradovich, S and Haigh, R. 2012. Stock Assessment for the inside population of yelloweye rockfish (Sebastes ruberrimus) in British Columbia, Canada for 2010. Fisheries and Oceans Canada, Science, Pacific Region.

\footnotetext{
How to cite this article: Andrews, K, Nichols, K, Harvey, C, Tolimieri, N, Obaza, A, Garner, R and Tonnes, D. 2019. All Hands on Deck: Local Ecological Knowledge and Expert Volunteers Contribute to the First Delisting of a Marine Fish Species Under the Endangered Species Act. Citizen Science: Theory and Practice, 4(1): 37, pp. 1-14. DOI: https://doi.org/10.5334/cstp.221

Copyright: (c) 2019 The Author(s). This is an open-access article distributed under the terms of the Creative Commons Attribution 4.0 International License (CC-BY 4.0), which permits unrestricted use, distribution, and reproduction in any medium, provided the original author and source are credited. See https://creativecommons.org/licenses/by/4.0/. 